\title{
A Study on the Effect of Teacher Written Feedback on College Students' Revision of Writing
}

\author{
Rong XIANG \\ School of Foreign Languages, Wuhan Textile University, Wuhan, 430073 China \\ E-mail: Lindaxr@126.com
}

Key words: College students; Revision of writing; Feedback; Teacher

\begin{abstract}
In this study, Associations between characteristics of the comments and the success of students' subsequent revisions are first examined. Then, the author sums up some common strategies adopted by the students when revising their compositions. In addition, three individual students were selected to examine in detail the factors that play a role in revision process through their Chinese revision reports. Finally, hopefully, the conclusions reached and strategies derived from this exploratory study can provide some new insights into the instruction and research into teacher written feedback of Chinese college English writing.
\end{abstract}

\section{Introduction}

Researchers abroad has examined the feedback on ESL students' writing to compare the differences and various efficacy of the two sources of feedback, the teacher feedback and the peer feedback, [1] to find out the students' preferences and reactions to the feedback (Cohen\&Cavalcanti, 1990; Hedgcock\& Lefkowitz, 1994,1996; Leki, 1991; Radecki\& Swales,1988), to see the effects of different focuses of teacher feedback (Fathman\&Whalley, 1990; Kepner, 1991; Master, 1995; Zamel, 1985; Conrad \& Goldstein 1999; Fazio, 2001; Chandler, 2003; Hyland, 2003), or to catalog various characteristics of teacher comments(Ferris, 1995). In the context of China, the research into ESL writing is still at a beginning stage. [2] There have been a few studies addressing teacher feedback in ESL writing, such as Yang's (1996) empirical study of effective feedback mechanism in improving English writing proficiency, Quo and Qin's (2008) literature review on the teacher written feedback research on L2 student writing abroad, Wang's (2012) study of teacher feedback on form errors in student's composition. Xu's (2015) case study in Guangzhou University on how effective error feedback is on self-correction in L2 writing. [3]The present study will consider the relationship between the teacher written feedback and the student revisions, looking first at what kind of characteristics of the teacher written feedback involved in successful revision, what strategies the student adopted when utilizing the feedback and then more closely investigating how this feedback was incorporated in the students' revisions in Chinese settings. In China, correcting students' writing is always considered as the teachers' main task and teacher written feedback dominates in the teaching of English writing. [4]However, the problem is always there that teacher spends abundant time and energy in providing feedback just failing to get satisfactory effect: the students utilize few teacher written feedbacks, even totally ignore them. [5] So, it is of great significance to examine what kind of characteristics of the teacher written feedback is involved in successful revision, what strategies the student adopts when utilizing the feedback and what factors like the background of the individual students, the context of situation to be associated with successful revision after teacher written feedback. [6] 


\section{Methodology}

\section{A. Subjects}

The subjects are 40 non-English major undergraduates from Wuhan Textile University (WTU), a key comprehensive university in Wuhan, central China. It is their first semester of the second year in this university.

\section{B. Instruments}

All compositions, the comment sheets, the revised versions and the students' reports in Chinese on their revision process were collected.

\section{Data collection}

All the 40 students attended the intensive reading course, which can be also called the comprehensive English course; the writing practice was included in the course, students were asked to write four essays as writing assignments outside class during a 16-week semester, topics mainly on exposition or argumentation.

\section{Results and Discussion}

In the first drafts collected from the subjects, there are 589 written interventions the teacher made from the composition. That is, the total number of feedback points is 589, in which contains the 483 revision directives. 332 feedback points on form and 151 feedback points on content are included in those revision directives.

\section{A. The Relationship between Form-focused Feedbacks and Revisions}

Table 1 Overview of the Total Teacher Written Feedback

\begin{tabular}{|c|c|c|}
\hline & & $\begin{array}{l}\text { Revision } \\
\text { success }\end{array}$ \\
\hline $\begin{array}{l}\text { Total number of teacher written feedback } \\
\text { points }\end{array}$ & 589 & \\
\hline Revision directives & 483 & \\
\hline Feedback on Form & $\begin{array}{l}332 \\
68.74 \%\end{array}$ & $\begin{array}{l}315 \\
95 \%\end{array}$ \\
\hline Feedback on Content & $\begin{array}{l}151 \\
31.26 \%\end{array}$ & $\begin{array}{l}71.5 \\
47.35 \%\end{array}$ \\
\hline
\end{tabular}

Table 1 easily shows that the feedbacks on form still take a high proportion in the Chinese students' articles. (332/483, accounting for 68.74\%)This may be partly explained by the student's language level but is also possibly partly the result of most Chinese teachers' habit, that is, the major focus of many Chinese teachers is still language form of the paper, they used to try to point out every grammatical errors and make the composition error free. In the student's posterior draft, the successful revision for the subjects comes to 315 in 325, accounting for 95\%. This may be the result of teacher's usual way of providing feedback on form. That is, forms or clues for the appropriate expression were most modeled above the location of the error. So, the students were able to successfully carry out these feedbacks.

\section{B. The Relationship between Content-focused Characteristics and Revisions}

In the analysis, the author began by looking at characteristics of the form of comments and found that from this perspective several of the characteristics seemed to be associated with revision success. However, we then reanalyzed the patterns in the data and discovered that, in fact, in almost all cases, just one characteristic, the type of problem to be revised, accounts for differences in success. Thus, as we discuss below, from data, it appears that it is misleading to focus on formal characteristics of the feedback without incorporating discussion of the type of revision that is being requested.

Tables 2 to 6 display the analysis of formal features of the written feedback. The data in the tables suggest that four of the five features in the category of formal characteristics have a 
relationship with success in revision.

Table 2 Relationship between Syntactic Structure and Revision Success

\begin{tabular}{|c|l|c|c|}
\hline \multirow{2}{*}{ Syntactic Structure } & \multicolumn{3}{|c|}{ Revision Success } \\
\cline { 2 - 4 } & Successful & $\begin{array}{c}\text { Not } \\
\text { Successful }\end{array}$ & $\begin{array}{c}\text { Not } \\
\text { Attempted }\end{array}$ \\
\hline \multirow{2}{*}{ Declaratives(N=83) } & $47.5 \mathrm{a}$ & 25.5 & 10 \\
& $57.20 \%$ & $37.72 \%$ & $12.05 \%$ \\
\hline \multirow{2}{*}{ Questions(N=57) } & 20.5 & 24.5 & 12 \\
& $35.96 \%$ & $42.98 \%$ & $21.52 \%$ \\
\hline \multirow{2}{*}{ Imperatives(N=11)b } & 3.5 & 7.5 & 0 \\
\hline
\end{tabular}

With regard to syntactic form, Table 2 appears that declaratives resulted in successful revision more often than questions did (57.20\% vs. 35.96\%).

Table 3 Relationship between Semantic/Pragmatic Content and Revision Success

\begin{tabular}{|c|c|c|c|}
\hline \multirow{2}{*}{$\begin{array}{l}\text { Semantic/Pragmatic } \\
\text { Content }\end{array}$} & \multicolumn{3}{|c|}{ Revision Suceess } \\
\hline & Successful & $\begin{array}{c}\text { Not } \\
\text { Successful }\end{array}$ & $\begin{array}{c}\text { Not } \\
\text { Attempted }\end{array}$ \\
\hline \multicolumn{4}{|l|}{ Declaratives $(\mathrm{N}=83)$} \\
\hline State Opinion $(\mathrm{N}=10)$ & $\begin{array}{l}6 \\
60 \%\end{array}$ & $\begin{array}{l}4 \\
40 \%\end{array}$ & 0 \\
\hline "Neod to" $(\mathrm{N}=36)$ & $\begin{array}{l}26 \\
72.22 \%\end{array}$ & $\begin{array}{l}5 \\
13.90 \%\end{array}$ & $\begin{array}{l}5 \\
13.90 \%\end{array}$ \\
\hline $\begin{array}{l}\text { Characterize } \\
\text { Test }(\mathrm{N}=21)\end{array}$ & $\begin{array}{l}6 \\
28.57 \%\end{array}$ & $\begin{array}{l}3 \\
42.85 \%\end{array}$ & $\begin{array}{l}2 \\
28.57 \%\end{array}$ \\
\hline Suggestion $(\mathrm{N}=16)$ & $\begin{array}{l}10.5 \\
65.63 \%\end{array}$ & $\begin{array}{l}3.5 \\
21.88 \%\end{array}$ & $\begin{array}{l}2 \\
12.5 \%\end{array}$ \\
\hline Question $(\mathrm{N}=57)$ & & & \\
\hline $\begin{array}{l}\text { supplying lexical } \\
\text { item/example })(\mathrm{N}=32)\end{array}$ & $\begin{array}{l}18.5 \\
57.81 \%\end{array}$ & $\begin{array}{l}8.5 \\
26.56 \%\end{array}$ & $\begin{array}{l}5 \\
15.63 \%\end{array}$ \\
\hline $\begin{array}{l}\text { WH Inform ation } \\
\text { Questions }(\mathrm{N}=25)\end{array}$ & $\begin{array}{l}4 \\
16 \%\end{array}$ & $\begin{array}{l}18 \\
72 \%\end{array}$ & $\begin{array}{l}3 \\
12 \%\end{array}$ \\
\hline $\begin{array}{l}\text { Either/Or } \\
\text { Questions }(\mathrm{N}=0)\end{array}$ & 0 & 0 & 0 \\
\hline
\end{tabular}

As far as semantic/pragmatic content is concerned, Table 3 appears that students revised successfully more often in response to declaratives of necessity or declaratives that made suggestions, rather than in response to declaratives that characterized their texts (about $72.22 \%$ and $65.63 \%$ vs. $28.57 \%$ ). For questions, students revised more successfully in response to yes/no questions than to WH questions (57.18\% vs. $16 \%$ ).

Table 4 Relationship between Directness and Revision Success

\begin{tabular}{|l|l|l|l|}
\hline \multirow{2}{*}{} & \multicolumn{3}{|c|}{ Revision Success } \\
\cline { 2 - 4 } & Successful & $\begin{array}{c}\text { Not } \\
\text { Successful }\end{array}$ & Not Attempted \\
\hline \multirow{2}{*}{ Direct(N=93) } & 63.5 & 15.5 & 14 \\
& $68.28 \%$ & $16.67 \%$ & $15.05 \%$ \\
\hline \multirow{2}{*}{ Indirect(N=58) } & 8 & 42 & 8 \\
& $13.79 \%$ & $72.41 \%$ & $13.79 \%$ \\
\hline
\end{tabular}

In table 4, direct comments were associated with successful revisions more commonly than indirect comments (68.28\% vs. $13.79 \%)$. 
Table 5 Relationship between Revision Strategy and Revision Success

\begin{tabular}{|c|l|c|c|}
\hline \multirow{2}{*}{} & \multicolumn{3}{|c|}{ Revision Success } \\
\cline { 2 - 4 } & Successful & $\begin{array}{c}\text { Not } \\
\text { Successful }\end{array}$ & Not Attempted \\
\hline Strategy & 60.5 & 9.5 & 16 \\
Included(N=86) & $70.35 \%$ & $11.05 \%$ & $18.60 \%$ \\
\hline Strategy Not & 11 & 48 & 6 \\
Included (N=65) & $16.92 \%$ & $73.85 \%$ & $0.92 \%$ \\
\hline
\end{tabular}

In table 5, revision directives that included a strategy, rather than those that did not were more often associated with successful revisions (70.35\% vs. $16.92 \%)$.

Table 6 Relationship between Hedges and Revision Success

\begin{tabular}{|c|l|c|l|}
\hline \multirow{2}{*}{} & \multicolumn{2}{|c|}{ Revision Success } & \multicolumn{2}{c|}{ Not Attempted } \\
\cline { 2 - 4 } & Successful & $\begin{array}{c}\text { Not } \\
\text { Successful }\end{array}$ & 3 \\
\hline \multirow{2}{*}{ Hedged(N=33) } & 20.5 & 9.5 & $0.91 \%$ \\
\hline Not & $62.12 \%$ & $28.79 \%$ & 19 \\
Hedged $(\mathrm{N}=118)$ & 51 & 48 & $16.10 \%$ \\
\hline
\end{tabular}

In Table 6, Only hedges appear to have little effect on subsequent revision; directives with hedges led to successful revision slightly more than half the time, while those without hedges led to successful revision slightly less than half the time.

Thus, at first glance, this analysis suggests that students revise more successfully in response to five characteristics of the feedback: (1) in general, declaratives rather than questions; (2) within declaratives, those that identify the necessity of revision or make suggestions, rather than declaratives that characterize the student's text; (3) within questions, yes/no questions rather than WH questions; (4) direct language rather than indirect language; and (5) inclusion of a specific revision strategy.

Table 7 Relationship between Type of Revision and Revision Success

\begin{tabular}{|c|c|c|c|}
\hline & \multicolumn{3}{|c|}{ Revision Success } \\
\hline & Successful & $\begin{array}{c}\text { Not } \\
\text { Suocessful }\end{array}$ & $\begin{array}{c}\text { Not } \\
\text { Attemptod }\end{array}$ \\
\hline \multirow{6}{*}{$\begin{array}{l}\text { All Areas Other Than } \\
\text { Development }(\mathrm{N}=36) \\
\text { Coherence/Cohesion }(\mathrm{N}=10) \\
\text { Paragraphing }(\mathrm{N}=12) \\
\text { Content }(\mathrm{N}=4) \\
\text { Purpose }(\mathrm{N}=4) \\
\text { Lexical Choice }(\mathrm{N}=6)\end{array}$} & $31.5(87.5 \%)$ & $1.5(4.17 \%)$ & $3(8.33 \%)$ \\
\hline & 10 & & \\
\hline & 10 & & 1 \\
\hline & 2 & 2 & \\
\hline & 4 & & \\
\hline & 6 & & \\
\hline \multirow{5}{*}{$\begin{array}{l}\text { Development }(\mathrm{N}=48) \\
\text { Type One }(\mathrm{N}=22) \\
\text { Add Examples }(\mathrm{N}=12)\end{array}$} & $13.5(28.13 \%)$ & $21.5(44.79 \%)$ & $13(27.83 \%)$ \\
\hline & $12(54.55 \%)$ & $2(9.1 \%)$ & $8(36.36 \%)$ \\
\hline & 11 & & 1 \\
\hline & & & 2 \\
\hline & 4 & 2 & 2 \\
\hline \multirow{2}{*}{$\begin{array}{r}\text { Type Two(N=26) } \\
\text { State/Address }\end{array}$} & $3.5(13.46 \%)$ & $18.5(71.15 \%)$ & $4(15.39 \%)$ \\
\hline & & 4 & 2 \\
\hline \multirow{2}{*}{$\begin{array}{l}\text { Explicitly }(\mathrm{N}=6) \\
\text { More Depth(N=6) } \\
\text { Expl ain/Analyze( }(\mathrm{N}=14)\end{array}$} & 3 & 3 & \\
\hline & & 9 & 5 \\
\hline
\end{tabular}

In table 7 , it is also found that there is a very strong relationship between the types of problem students were asked to revise and the success of revisions. In response to problems other than development (i.e., coherence/cohesion, paragraphing, content, purpose, and lexical choice), students almost always revised successfully (approximately 90\% of the occurrences). However, of the 48 revision directives focused on development, less than $30 \%$ resulted in successful revisions. 
Table 8 Relationship between Type of Revision Problem and Revision Success across Category Types

\begin{tabular}{|c|c|c|c|c|}
\hline & \multicolumn{2}{|c|}{$\begin{array}{l}\text { Explanation/A nalysis/E } \\
\text { xplic itness }\end{array}$} & \multicolumn{2}{|c|}{ Other Problem } \\
\hline & $\begin{array}{l}\text { Total } \\
\text { Number(N } \\
=19)\end{array}$ & $\begin{array}{l}\text { Number } \\
\text { Successfully } \\
\text { Revisod(N=3) }\end{array}$ & $\begin{array}{l}\text { Tokal } \\
\text { Number } \\
(\mathrm{N}=47)\end{array}$ & \begin{tabular}{l}
\multicolumn{1}{c}{ Number } \\
Successfully \\
Revisod( $\mathrm{N}=435)$
\end{tabular} \\
\hline \multicolumn{5}{|l|}{ Syntactic Category } \\
\hline \multirow{2}{*}{$\begin{array}{l}\text { Declarative }(\mathrm{N}=73) \\
\qquad \text { Question }(\mathrm{N}=45)\end{array}$} & 105 & 3 & 42.5 & 31.5 \\
\hline & 85 & 0 & 4.5 & 12 \\
\hline \multicolumn{5}{|l|}{$\begin{array}{l}\text { Semantic/Pragmati } \\
\text { c Content }\end{array}$} \\
\hline Dechatives & 1 & 0 & 0 & $-\cdot$ \\
\hline \multirow{5}{*}{$\begin{array}{c}\text { Stac } \\
\text { opinion( } \mathrm{N}=10) \\
\text { Need to( } \mathrm{N}=36) \\
\text { Characterize } \\
\text { text }(\mathrm{N}=21) \\
\text { Suggesion }(\mathrm{N}=16)\end{array}$} & 2 & 3 & 24 & 26.5 \\
\hline & 3 & 0 & 5 & 6 \\
\hline & 1 & 0 & 9.5 & 55 \\
\hline & & & & \\
\hline & 1 & 0 & 9.5 & 55 \\
\hline $\begin{array}{l}\text { Suggestion }(\mathrm{N}=16) \\
\text { Questions } \\
\text { Yes/no(N=32) } \\
\text { WH(N=25) }\end{array}$ & 11 & 0 & 0 & -. \\
\hline \multicolumn{5}{|l|}{ Directness } \\
\hline \multirow{2}{*}{$\begin{array}{l}\operatorname{Direct}(\mathrm{N}=93) \\
\text { Indirect( } \mathrm{N}=58)\end{array}$} & 5 & 3 & 35 & 35 \\
\hline & 14 & 0 & 12 & 85 \\
\hline \multicolumn{5}{|l|}{ Revision Srategy } \\
\hline \multirow{2}{*}{$\begin{array}{l}\text { Included(N=86) } \\
\mathrm{N \alpha} \\
\text { included }(\mathrm{N}=65)\end{array}$} & 0 & 0 & 35 & 35 \\
\hline & 19 & 3 & 12 & 85 \\
\hline
\end{tabular}

Table 8 displays the relationship between the type of revision problem and revision success across comment characteristics. Thus, Table 8 shows that if the problem to be revised focused on explanation, explicitness, or analysis, the resulting revisions were almost never successful. The patterns in Table 8 provide an explanation for the initial analyses, where it appeared that certain formal characteristics of the feedback were associated with revision success. The comments that possess the individual formal characteristics that were more often associated with successful revisions concentrate on problems other than explanation, analysis, and explicitness.

\section{The relationship between type of revision required and success of revision}

It is not wished to imply that the form of a teacher's comments is entirely unimportant. It does seem that, in some cases in this study, students misinterpreted the intended meaning of the teacher's comments. Sun Yao seemed not to understand that the teacher's 'how and why' questions in his paper about working women who were meant to convey her disagreement with his claims and to get him to examine his claims more carefully. Li Mei appeared not to understand that a statement about having three separate points meaning that she should have three separate paragraphs. However, it was not possible to identify characteristics of feedback that were consistently associated with students' misinterpretations. 1n most cases, even very indirect and hedged suggestions were followed by the students.

\section{The Strategies adopted concerning the teacher written feedback in revision}

The strategies the students adopted between the written feedback offered and the revisions made was examined in more detail. The data suggested that students' revisions could be related to the feedback in three different ways. Firstly, revisions often closely followed the corrections or suggestions made by the feedback. Second, feedback could act as an initial stimulus. This means it could trigger a number of revisions which went beyond the issues addressed by the initial feedback. The teacher's focus on one problematic item sometimes stimulated revisions which spanned a whole sentence or a number of sentences and involved different aspects of the text. 


\section{Conclusion}

\section{A. Major Findings}

For the relationship between students' revisions and particular characteristics of the written feedback, the study suggests that students revise more successfully in response to five characteristics of the feedback: (1) in general, declaratives rather than questions; (2) within declaratives, those that identify the necessity of revision or make suggestions, rather than declaratives that characterize the student's text; (3) within questions, yes/no questions rather than WH questions; (4) direct language rather than indirect language; and (5) inclusion of a specific revision strategy. Second, it is also found that there is a very strong relationship between the types of problem students were asked to revise and the success of revisions; students tended to be successful in resolving many types of revision problems (e.g., adding examples, increasing cohesion), but they were unsuccessful in revising problems related to explanation, explicitness, and analysis. Third, it appeared that five characteristics were associated with successful revision; it also can be found that these five characteristics are all used.

\section{B. Limitations and Suggestions for Research}

This study focused on three writers in one setting; clearly, more research needs to be done in which writers are examined at different levels in a range of settings. The results of this study indicated again that each of students has uniqueness as a writer, and we advocate more work in which we can look closely at individual students and their revisions in response to feedback to identify many factors that affect students as they revise.

\section{References}

[1] Ashwell, T. (2000). Patterns teacher response to student writing in a multiple-draft composition classroom: Is content feedback followed by form feedback the best method? [J]. Journal of Second Language Writing, 9 (3), 227-257

[2] Cheng, W.,\&Warren, M. (2005). Peer assessment of language proficiency. Language Testing, 22(1), 93-121.

[3]Conrad, S. \& Goldsmith, L. (1999). ESL student revision after teacher-written comments: Text, contexts, and individuals [J]. Journal of Second Language Writing, 8 (3), 147-180

[4]Fathman, A \&. Whalley, E. (1990). Teacher response to student writing: Focus on forem versus content. In Barbara Kroll (Ed.) Second Language Writing: Research Insights for the Classroom. Cambridge: Cambridge University Press, 178-190.

[5]Ferris, D. \& Roberts. B, (2001), Error feedback in L2 writing classes: How explicit does it need to be? [J]. Journal of Second Language Writing, 10 (3), 161-184.

[6]Hillocks, G. (1986). Research on Written Composition: New Directions for Teaching. Urbana, IL: ERIC Clearinghouse on Reading and Communication Skills and the National Conference on Research in English. 